\title{
Aplikasi Pengamanan Informasi Menggunakan Metode Least Significant Bit (Lsb) dan Algoritma Kriptografi Advanced Encryption Standard (AES)
}

\author{
Dian Novianto $^{1)}$, Yohanes Setiawan ${ }^{2)}$ \\ ${ }^{1) 2)}$ Program studi Teknik Informatika, STMIK Atma Luhur \\ Jl. Jendral Sudirman, Selindung Baru, Kec. Gabek Pangkal pinang Kode Pos 33117 \\ Email :diannovianto@atmaluhur.ac.id ${ }^{1)}$,ysetiawanj@atmaluhur.ac.id ${ }^{2)}$
}

\begin{abstract}
There are several security aspects of the data that must be maintained, such as: authentication, integrity, non repudiation, authority, confidentialty, privacy and access control. One of the vulnerable parts of data security is when sending data to the destination. At the time of delivery, tapping of data can occur, so that people who are not entitled to get that information can find out. Therefore, an information needs to be secured so that only people who have access rights can know or get that information. And to maintain the confidentiality of the information, one of the ways is to insert the data into other objects, so that other people do not realize if the object contains important data or information. This hiding method is also known as steganography, and cryptography is added to strengthen the security of the data, that is a science and art to maintain the confidentiality of the message by encoding it in a form that is incomprehensible. The method used in steganography is Least Significant Bit (LSB), the algorithm used in cryptography is the Advanced Encryption Standard (AES), and the software development method used is prototype. The results of this study are all aspects of data security can be achieved, including when passing through the process of sending data through media such as the internet.
\end{abstract}

Keyword: Steganography, Criptography, Prototype.

\begin{abstract}
Abstrak
Ada beberapa aspek keamanan data yang harus dijaga, seperti: otentikasi, integritas, non repudiation, otoritas, kerahasiaan, privasi, dan kontrol akses. Salah satu bagian yang rentan dari keamanan data adalah ketika mengirim data ke tujuan. Pada saat pengiriman, penyadapan data dapat terjadi, sehingga orang yang tidak berhak mendapatkan informasi tersebut dapat mengetahuinya. Oleh karena itu, suatu informasi perlu diamankan sehingga hanya orang yang memiliki hak akses yang dapat mengetahui atau mendapatkan informasi tersebut. Dan untuk menjaga kerahasiaan informasi, salah satu caranya adalah dengan memasukkan data ke objek lain, sehingga orang lain tidak menyadari jika objek tersebut berisi data atau informasi penting. Metode persembunyian ini juga dikenal sebagai steganografi, dan kriptografi ditambahkan untuk memperkuat keamanan data, yaitu ilmu dan seni untuk menjaga kerahasiaan pesan dengan menyandikannya dalam bentuk yang tidak dapat dipahami. Metode yang digunakan dalam steganografi adalah Least Significant Bit (LSB), algoritma yang digunakan dalam kriptografi adalah Advanced Encryption Standard (AES), dan metode pengembangan perangkat lunak yang digunakan adalah prototipe. Hasil dari penelitian ini adalah semua aspek keamanan data dapat dicapai, termasuk ketika melewati proses pengiriman data melalui media seperti internet.
\end{abstract}

Kata kunci: Steganografi, kriptografi, Prototipe 


\section{Pendahuluan}

Pada era digital saat ini pengiriman data melalui media internet merupakan hal yang biasa, dimana masyarakat sudah memiliki perangkat dan akses terhadap jaringan internet yang cukup memadai. Dalam penyampaian informasi menggunakan media internet membutuhkan suatu tingkat keamanan data, agar data tidak dapat diakses oleh orang yang tidak memiliki izin sehingga kerahasiaannya dapat terjaga. Ada beberapa ancaman-ancaman yang dapat terjadi melalui jaringan internet yang harus di waspadai, hal tersebut bisa berupa interupsi, penyadapan, modifikasi maupun fabrikasi.

Oleh karena itu untuk menjamin kerahasiaan dari informasi yang akan dikirimkan melalui media seperti internet, informasi harus diletakan pada wadah pembawa yang dapat memperkuat tingkat keamanan dari informasi. Wadah dari informasi ini merupakan sebuah media yang dapat berbentuk berbagai jenis berkas, seperti berkas gambar, berkas suara, maupun berkas dokumen. Sehingga informasi tidak akan dikenali secara langsung oleh orang yang berniat untuk mendapatkan informasi tersebut tanpa hak akses.

Proses menyembunyikan informasi kedalam sebuah wadah pembawa dapat dilakukan dengan menggunakan berbagai metode dan variasi. Salah satunya adalah dengan menggunakan teknik steganografi, selain itu juga dapat ditambahkan teknik untuk dilakukan pengacakan informasi dengan kunci tertentu sehingga informasi tidak diketahui artinya, teknik ini juga dikenal dengan nama kriptografi. Untuk menyelesaikan teknik steganografi ini dapat menggunakan beberapa metode, antara lain: Least Significant Bit (LSB), End Of File (EOF), Discrete Cosine Transform (DCT), Discrete Wavelet Transform $(D W T)$ dan lain - lain, sedangkan algoritma kriptografi sendiri terdiri dari 2 jenis, yaitu asmetri kriptografi dan simetri kriptografi, perbedaan dari keduanya adalah dari kunci yang digunakan. Untuk algoritma kriptografi asimetri sering juga disebut dengan algoritma kunci publik, yaitu kunci untuk melakukan enkripsi dan dekripsi berbeda, menggunakan kunci public dan kunci privat, seperti: Digital Signature Algorithm (DSA), Rivest Shamir Adleman (RSA), Diffie Hellman (DH), Quantum, dan lain sebaganya. Sedangkan algoritma kriptografi simetri sering disebut dengan algoritma klasik karena menggunakan kunci yang sama untuk melakukan proses enkripsi dan dekripsi, seperti: Data Encription Standard (DES), Advanced Encryption Standard (AES), International Data Encryption Algorithm (IDEA) One Time Pad (OTP) dan lain sebagainya $^{[1]}$.

Metode yang digunakan dalam steganografi pada penelitian ini adalah Least Significant Bit (LSB) dan algoritma kriptografi yang digunakan adalah simetri kriptografi yaitu Advanced Encryption Standard (AES).

Metode LSB (Least Significant Bit) merupakan salah satu teknik substitusi pada steganografi. Dimana tiap bit terendah pada byte-byte media citra akan digantikan dengan bit-bit pesan yang akan disisipkan. Pada file citra
24 bit setiap pixel pada citra terdiri dari susunan tiga warna, yaitu merah, hijau dan biru (RGB) yang masingmasing disusun oleh bilangan 8 bit ( 1 byte) dari 0 sampai 255 atau dengan format biner 00000000 sampai $11111111^{[2]}$.

Metode LSB merupakan metode steganografi yang paling sederhana dan mudah diimplementasikan. Metode ini menggunakan citra digital sebagai covertext. Pada susunan bit di dalam sebuah byte ( 1 byte $=8$ bit), ada bit yang paling depan (most significant bit atau MSB) dan bit yang paling akhir (least significant bit atau LSB ${ }^{{ }^{[3]}}$.

Advanced Encryption Standard (AES) merupakan algoritma cryptographic yang dapat digunakan untuk mengamankan data. Algoritma AES adalah blok chipertext simetrik yang dapat mengenkripsi (encipher) dan dekripsi (decipher) informasi. Enkripsi merubah data yang tidak dapat lagi dibaca disebut ciphertext, sebaliknya dekripsi adalah merubah ciphertext data menjadi bentuk semula yang kita kenal sebagai plaintext $^{[4]}$.

AES ini merupakan algoritma block cipher dengan menggunakan sistem permutasi dan substitusi $(P-B o x$ dan $S$-Box) bukan dengan jaringan Feistel sebagaiman block cipher pada umumnya. Jenis AES terbagi 3, yaitu AES-128, AES-192, AES-256. Pengelompokkan jenis AES ini adalah berdasarkan panjang kunci yang digunakan $^{[5]}$.

Diperlukan pengujian dalam penelitian ini untuk mengetahui cara kerja dari teknik steganografi yang menggunakan metode LSB maupun kriptografi dengan algoritma AES, seperti proses encoding dari gambar yang kemudian akan disisipkan pesan rahasia yang telah terenkripsi, serta proses decoding gambar untuk mengeluarkan file rahasia yang terenkripsi untuk kemudian dilakukan proses dekripsi pada file rahasia nya.

Model pengembangan perangkat lunak yang digunakan dalam penelitian ini adalah prototype. Model prototype merupakan sesuatu yang harus dievaluasi dan di modifikasi kembali, segala perubahan dapat terjadi pada saat prototype dibuat untuk memenuhi kebutuhan pengguna dan pada saat yang sama memungkinkan pengembang untuk lebih memahami kebutuhan pengguna secara lebih baik. Model prototype dimulai dengan pengumpulan kebutuhan pengguna ${ }^{[6]}$.

Dalam penelitian ini tools pengembangan yang digunakan adalah UML. UML atau Unified Modeling Language merupakan perangkat lunak yang berparadigma "berorientasi objek". Pemodelan (modeling) sesungguhnya digunakan untuk penyederhanaan permasalahan-permasalahan yang kompleks sedemikian rupa sehingga lebih mudah dipelajari dan dipahami ${ }^{[7]}$.

\section{A. Metode Penelitian}

Metode yang digunakan dalam penelitian ini menggunakan metode kualitatif dimana peneliti menjadi alat utama dalam pengumpulan data ${ }^{[8]}$. Pengumpulan data yang peneliti lakukan dengan cara mencari referensi 
yang terkait dengan topic penelitian dari jurnal maupun buku. Dengan cara tersebut peneliti dapat memahami cara kerja dari metode dan algoritma yang dipakai, sehingga diharapkan dalam pengembangan perangkat lunak nantinya akan berjalan dengan baik dan lancar.

Dalam pengembangan sistem dengan model Prototype, model ini memiliki beberapa tahapan yang harus diikuti oleh peneliti, antara lain: Pengumpulan kebutuhan, membangun prototyping, evaluasi prototyping, mengkodekan sistem, menguji sistem dan evaluasi sistem.

Dan dalam pengembangan sistem, spesifikasi kebutuhan perangkat keras dan perangkat lunak yang peneliti gunakan dalam penelitian ini, seperti pada tabel 1 dibawah ini:

Tabel 1 Perangkat yang digunakan

\begin{tabular}{|l|l|}
\hline \multicolumn{1}{|c|}{ Perangkat Lunak } & \multicolumn{1}{|c|}{ Perangkat Keras } \\
\hline Windows 8.1 Pro & $\begin{array}{l}\text { Laptop dengan Spesifikasi: } \\
\text { Processor A8-4500M up to }\end{array}$ \\
\cline { 1 - 1 } Visual Basic 6.0 & $\begin{array}{l}2.80 \text { GHz, GPU: AMD } \\
\text { Cryptool 2 }\end{array}$ \\
\cline { 1 - 2 } $\begin{array}{l}\text { Astah Community } \\
7.1 .0\end{array}$ & 4GB, HDD 500GB \\
\hline
\end{tabular}

Tahapan yang peneliti lakukan dalam mengembangkan perangkat lunak pengamanan informasi dengan model prototype akan diuraikan seperti pada bagian bawah ini, antara lain :

1. Pengumpulan kebutuhan.

Pada tahap pertama ini dilakukan pengumpulan kebutuhan dengan cara mengumpulkan berbagai data yang diperlukan berupa referensi dari jurnal ilmiah maupun buku yang berkaitan dengan pembahasan yang akan peneliti lakukan, yaitu steganografi dengan metode LSB dan kriptografi dengan algoritma AES.

\section{Membangun prototyping.}

Setelah data yang dikumpulkan dirasa cukup untuk menunjang pengembangan sistem, pada tahap yang kedua peneliti melakukan proses analisis dan perancangan sistem berdasarkan hasil kesimpulan dari data yang sudah dikumpulkan. Perancangan yang dilakukan menggunakan tools UML untuk memberikan gambaran dari bentuk sistem nantinya. Terdiri dari activity diagram, dan use case.

\section{Evaluasi prototyping.}

Pada tahapan ketiga yang peneliti lakukan dalam evaluasi prototyping yaitu proses evaluasi prototyping yang sudah dirancang sebelumnya, apakah telah sesuai dengan kebutuhan atau belum. Jika sudah sesuai maka dilakukan proses selanjutnya. Tetapi jika belum sesuai, maka akan dilakukan pengecekan pada proses sebelumnya atau kembali ke tahap pertama.evaluasi ini dilakukan dengan cara melihat rancangan pada UML yang dibuat untuk kemudian dibandingkan dengan data yang sudah dikumpulkan pada tahapan pertama.
4. Mengkodekan sistem.

Jika pada tahapan evaluasi, desain sudah sesuai atau memenuhi kebutuhan pengguna, maka akan lanjut pada tahapan keempat, yaitu dilakukan proses pengkodean sistem dengan membuat program menggunakan bahasa pemrograman visual studio 2010 berdasarkan rancangan yang sudah dibuat sebelumnya.

\section{Menguji sistem.}

Pada tahapan kelima yaitu pengujian sistem, aplikasi yang sudah dibangun akan diuji dengan menggunakan metode Black Box untuk mengetahui fungsi dari sistem apakah sudah berjalan dengan baik atau masih terdapat kekurangan/kesalahan. Selain pengujian fungsi, dilakukan pengujian data dengan melihat data dari berkas yang dijadikan sampel, untuk melihat ada tidaknya perubahan kualitas dari informasi.

6. Evaluasi sistem.

Setelah tahapan pengujian selesai, tahapan selanjutnya adalah evaluasi sistem. Dimana pada tahapan evaluasi sistem ini jika terdapat perubahan yang diminta oleh penguji program, maka peneliti akan kembali pada tahapan keempat yaitu memperbaiki pengkodean sistem sesuai dengan permintaan penguji.

\section{Menggunakan sistem.}

Pada tahapan terakhir model pengembangan prototype, sistem yang sudah dievaluasi dan sudah dinyatakan lolos oleh penguji program, maka aplikasi pengamanan informasi sudah siap untuk diimplementasikan atau digunakan.

Dari hasil analisa data pada tahapan pertama model prototype, maka didapatlah hasil dalam bentuk diagram dengan menggunakan UML sebagai tool pengembangan perangkat lunak dimana dalam penggambaran ini peneliti menggunakan astah community, hal ini dimaksudkan untuk mempermudah dalam penggambaran proses bisnis yang terjadi. Seperti pada gambar 1 activity diagram sistem berjalan dibawah ini:

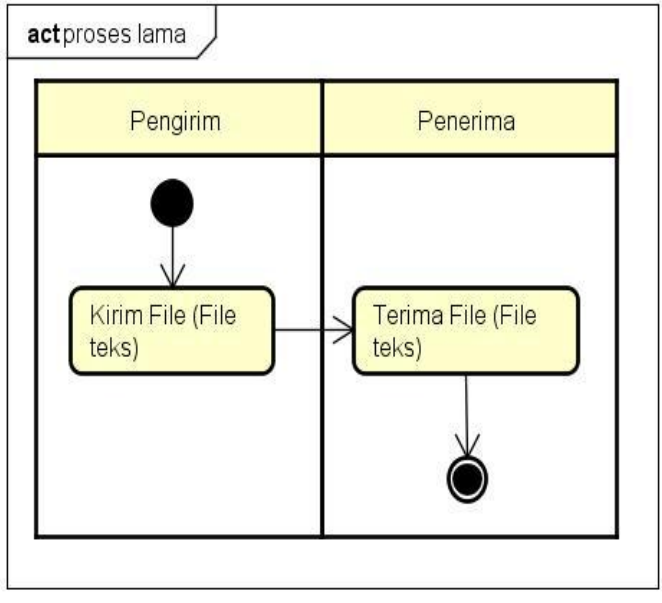

Gambar 1. Acitivity Diagram Sistem Berjalan 
Dari gambar diatas diketahui bahwa proses yang banyak terjadi dari hasil analisa adalah, orang langsung mengirimkan berkas/file secara langsung ke tujuan tanpa adanya tambahan usaha untuk mengamankan informasi. Dari hasil tersebut dirancanglah prototype berupa use case diagram usulan pada sistem yang baru, ditunjukkan seperti gambar 2 dibawah ini:

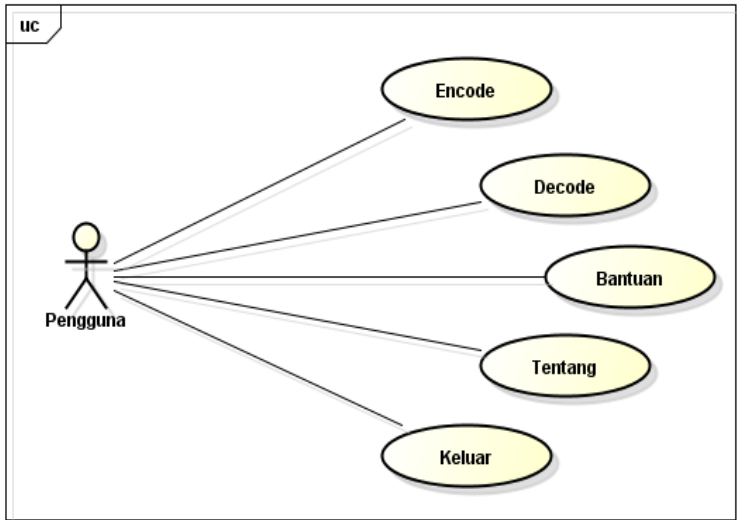

Gambar 2. Use case usulan sistem

Use case diagram diatas merupakan rancangan untuk sistem yang akan dibangun, untuk mengetahui fungsi apa saja yang tersedia di aplikasi. Use case diagram diatas dibuat berdasarkan hasil analisa dari kebutuhan pengguna. Dimana kebutuhan pengguna disini adalah penyisipan berkas dan enkripsi, serta dekripsi dan ekstraksi berkas, dengan tambahan menu bantuan untuk cara penggunaan dari aplikasi, menu tentang untuk mengetahui fungsi dari aplikasi, dan menu keluar untuk menutup aplikasi.

\section{Hasil dan Pembahasan}

Pada bagian ini akan dibahas hasil dari perancangan dalam bentuk jadi berupa tangkapan layar dari aplikasi dan hasil pengujian aplikasi.

\section{A. Tampilan Form Utama}

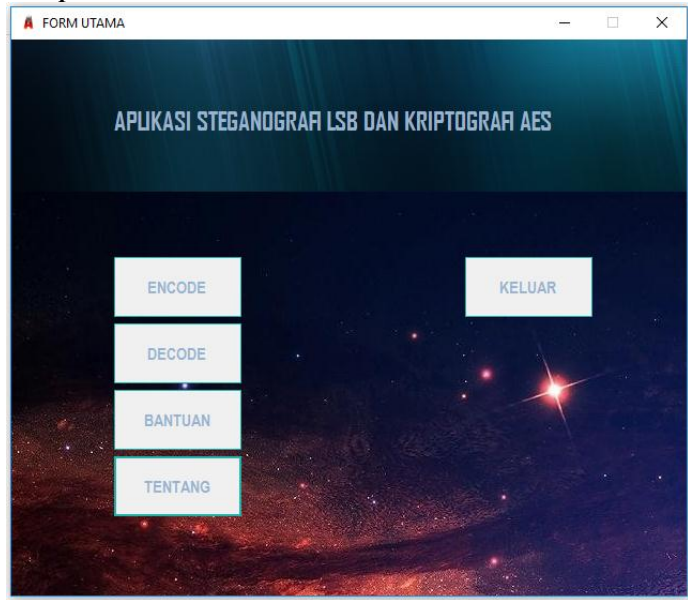

Gambar 3. Form Utama
Dimana pada tampilan utama, terdiri dari lima menu, yaitu encode yang berfungsi untuk melakukan penyisipan dan enkripsi data atau informasi kedalam gambar, menu decode berfungsi untuk mengeluarkan data atau informasi rahasia dari gambar, menu bantuan untuk mengetahui cara penggunaan dari aplikasi, menu tentang untuk mengetahui fungsi dari aplikasi, dan menu keluar untuk menutup aplikasi.

\section{B. Tampilan Form Encode}

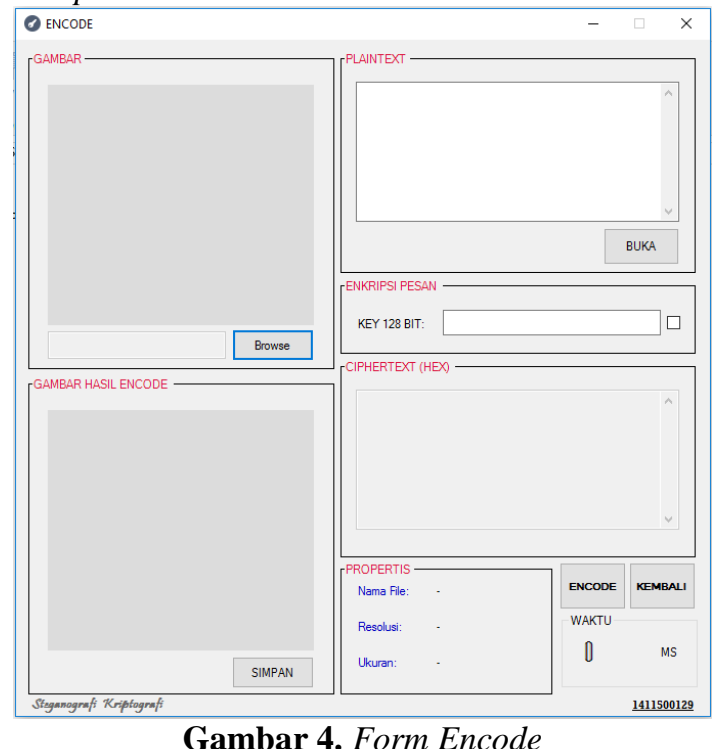

Pada gambar 4 diatas, pengguna dapat memasukkan data atau informasi dalam bentuk huruf yang ingin di sembunyikan kedalam sebuah gambar, selain itu juga pengguna diharuskan memasukkan kunci kriptografi AES sepanjang 128 bit, dimana waktu berfungsi menampilkan jumlah waktu yang dibutuhkan untuk memproses penyisipan data, dimana proses pertama dilakukan enkripsi menggunakan kunci tertentu, dan hasilnya akan berupa chipertext hexadecimal, setelah itu baru kemudian chipertext akan disisipkan kedalam gambar sebagai wadah informasi yang ingin di amankan.

c. Tampilan Form Decode

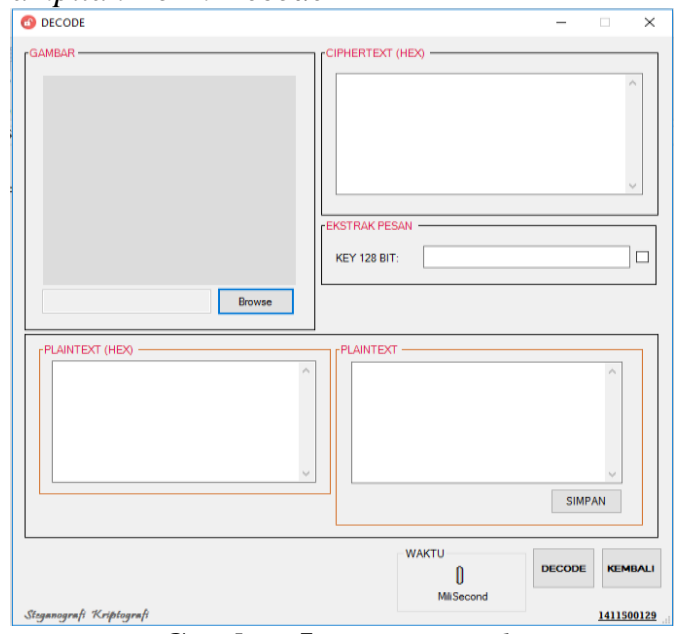

Gambar 5. Form Decode 
Selanjutnya, pada bagian decode, pengguna yang mendapatkan data atau informasi yang tersimpan didalam gambar dapat mengeluarkan informasi tersebut dengan mencari gambar melalui menu browse, dan secara otomatis akan muncul pesan dalam bentuk chipertext hexadecimal untuk menerjemahkan, pengguna diharuskan memasukkan kunci yang sama pada saat enkripsi sepanjang 128 bit, maka pesan akan secara otomatis dikembalikan kedalam bentuk semula atau plaintext dalam dua jenis, yaitu plaintext hexadecimal dan plaintext biasa.

\section{Tampilan Form Bantuan}

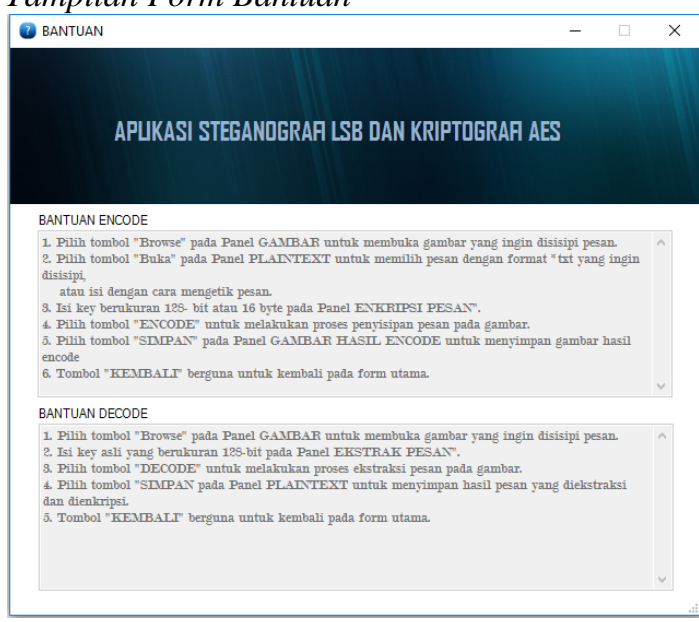

Gambar 6. Form Bantuan

Pada form bantuan, pengguna dapat membaca langkah - langkah yang harus dilakukan ketika menggunakan aplikasi pengamanan data ini.

\section{E. Tampilan Form Tentang}

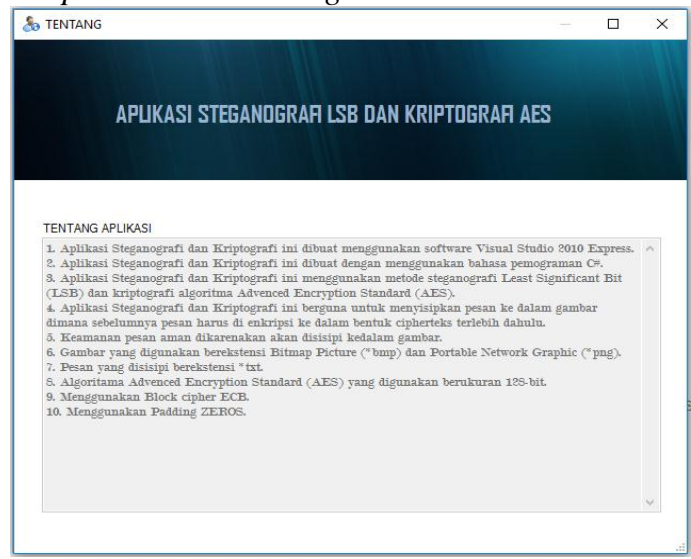

Gambar 7. Form Tentang

Pada form tentang, pengguna dapat membaca fungsi dari aplikasi yang dibuat, metode pengamanan dan algoritma yang digunakan.

\section{a. Pengujian}

Pada pengujian yang dilakukan pada aplikasi steganografi dan kriptografi ini, ada dua hal yang diujikan yaitu pengujian fungsi menggunakan metode blackbox dan pengujian data berupa pengujian fidelity dengan hasil, antara lain:

1. Pengujian fungsi dengan metode blackbox

a. Pengujian pertama dilakukan pada menu encode, dimana hasil dari pengujian dapat dilihat pada tabel 2 dibawah ini:

Tabel 2. Pengujian fungsi encode

\begin{tabular}{|c|c|c|c|c|}
\hline No & $\begin{array}{c}\text { Kasus } \\
\mathrm{Uji}\end{array}$ & Skenario & $\begin{array}{l}\text { Hasil yang } \\
\text { Diharapkan }\end{array}$ & $\begin{array}{c}\text { Keteran } \\
\text { gan }\end{array}$ \\
\hline 1 & \begin{tabular}{|l|} 
Melakuk \\
an \\
proses \\
encode.
\end{tabular} & $\begin{array}{l}\text { Tidak memasukkan pesan, } \\
\text { tidak memasukkkan gambar, } \\
\text { dan tidak memasukkan key. } \\
\text { Lalv menekan tombol } \\
\text { "ENCODE". }\end{array}$ & $\begin{array}{l}\text { Aplikasi tidak akan } \\
\text { melakukan proses encode } \\
\text { dan akan menampilkan } \\
\text { message "Data tidak ada } \\
\text { boleh yang kosong!" }\end{array}$ & Berhasil \\
\hline 2 & \begin{tabular}{|l|} 
Melakuk \\
an \\
proses \\
encode.
\end{tabular} & $\begin{array}{l}\text { Memasukkan gambar(bmp, } \\
\text { png ), tapi tidak memasukkan } \\
\text { pesan, dan tidak memasukkan } \\
\text { key . Lalv menekan tombol } \\
\text { "ENCODE". }\end{array}$ & $\begin{array}{l}\text { Aplikasi tidak akan } \\
\text { melakukan proses encode } \\
\text { dan akan menampilkan } \\
\text { message "Pesan yang ingin } \\
\text { anda sembunyikan tidak } \\
\text { boleh yang kosong!" }\end{array}$ & Berhasil \\
\hline 3 & \begin{tabular}{|l|} 
Melakuk \\
an \\
proses \\
encode.
\end{tabular} & $\begin{array}{l}\text { Memasukkan } \\
\text { gambar(bmp,png), } \\
\text { memasukkan pesan, dan tidak } \\
\text { memasukkan ksy. Lalv } \\
\text { menekan tombol "ENCODE". }\end{array}$ & $\begin{array}{l}\text { Aplikasi tidak akan } \\
\text { melakukan proses encode } \\
\text { dan akan menampilkan } \\
\text { message "Key tidak boleh } \\
\text { kosong!" }\end{array}$ & Berhasil \\
\hline 4 & \begin{tabular}{|l|} 
Melakuk \\
an \\
proses \\
encode.
\end{tabular} & $\begin{array}{l}\text { Memasukkan gambar(bmp, } \\
\text { png ), memasukkan pesan, dan } \\
\text { memasukkan ksy. Lalv } \\
\text { menekan tombol "ENCODE". }\end{array}$ & $\begin{array}{l}\text { Berhasil mengenkripsi } \\
\text { pesan dan menampilkan } \\
\text { hasil ciphertext (hex), } \\
\text { berhasil menampilkan } \\
\text { gambar hasil encode di } \\
\text { panel "GAMBAR HASIL } \\
\begin{array}{l}\text { Proses encode berjalan } \\
\text { lancar. }\end{array} \\
\end{array}$ & Berhasil \\
\hline 5 & $\begin{array}{l}\text { Menam } \\
\text { pilkan } \\
\text { halaman } \\
\text { browse } \\
\text { memilih } \\
\text { gambar( } \\
\text { bmp. }\end{array}$ & $\begin{array}{l}\text { Pengguna memilih tombol } \\
\text { "Browse" }\end{array}$ & $\begin{array}{l}\text { Aplikasi menampilkan } \\
\text { halaman browse untvk } \\
\text { memilih gambar (bmp. } \\
\text { png) yang ada pada media } \\
\text { penyimpanan }\end{array}$ & Berhasil \\
\hline 6 & \begin{tabular}{|l|} 
Menam \\
pilkan \\
halaman \\
browse \\
memilih \\
pesan $(t x$ \\
t) \\
\end{tabular} & $\begin{array}{l}\text { Pengguna memilih tombol } \\
\text { "BUKA" }\end{array}$ & $\begin{array}{l}\text { Aplikasi menampilkan } \\
\text { halaman browse untuk } \\
\text { memilih pesan (txt) yang } \\
\text { ada pada media } \\
\text { penyimpanan }\end{array}$ & Berhasil \\
\hline 7 & $\begin{array}{l}\text { Berganti } \\
\text { tampila } \\
\text { n image } \\
\text { view }\end{array}$ & $\begin{array}{l}\text { Melakukan proses pilih } \\
\text { gambar(bmp,png) dan } \\
\text { menekan tombol "Open" }\end{array}$ & $\begin{array}{l}\text { Image view berhasil } \\
\text { berganti, dan menampilkan } \\
\text { propertis gambar }\end{array}$ & Berhasil \\
\hline 8 & \begin{tabular}{|l|} 
Menam \\
pilkan \\
pesan(tx \\
t) yang \\
dipilih. \\
\end{tabular} & $\begin{array}{l}\text { Melakukan proses pilih pesan } \\
(\text { txt ) dan menekan tombol } \\
\text { "Open" }\end{array}$ & $\begin{array}{l}\text { Pesan teks berhasil } \\
\text { ditampilkan. }\end{array}$ & Berhasil \\
\hline 9 & \begin{tabular}{|l|} 
Menyim \\
pan \\
gambar.
\end{tabular} & $\begin{array}{l}\text { Melakukan proses menyimpan } \\
\text { gambar dengan menekan } \\
\text { tombol "SIMPAN" }\end{array}$ & $\begin{array}{l}\text { Aplikasi berhasil } \\
\text { menyimpan } \\
\text { gambar(bmp,png) }\end{array}$ & Berhasil \\
\hline 10 & $\begin{array}{l}\text { Kembali } \\
\text { ke menv } \\
\text { utama }\end{array}$ & $\begin{array}{l}\text { Pengguna memilih tombol } \\
\text { "KEMBALI" }\end{array}$ & $\begin{array}{l}\text { Aplikasi melakukan proses } \\
\text { kembali ke menv utama }\end{array}$ & Berhasil \\
\hline
\end{tabular}

b. Pengujian kedua dilakukan pada menu decode, dimana hasil dari pengujian dapat dilihat pada tabel 3 dibawah ini: 
Tabel 3. Pengujian fungsi decode

\begin{tabular}{|c|c|c|c|c|}
\hline \multirow{2}{*}{ No } & Kasus & \multirow[t]{2}{*}{ Skenario } & Hasil yang & \multirow{2}{*}{\begin{tabular}{|c|}
$\begin{array}{c}\text { Keteran } \\
\text { gan }\end{array}$ \\
\end{tabular}} \\
\hline & $\mathrm{Uji}_{\mathrm{ji}}$ & & Diharapkan & \\
\hline 1 & \begin{tabular}{|l|} 
Memilih \\
gambar \\
hasil \\
decode
\end{tabular} & $\begin{array}{l}\text { Pengguna memilih tombol } \\
\text { "Browse" }\end{array}$ & $\begin{array}{l}\text { Aplikasi menampilkan } \\
\text { halaman browse untuk } \\
\text { memilih gambar (bmp. } \\
\text { png) yang ada pada media } \\
\text { penyimpanan }\end{array}$ & Berhasil \\
\hline 2 & \begin{tabular}{|l|} 
Melakuk \\
an \\
proses \\
decode
\end{tabular} & $\begin{array}{l}\text { Memasuikkan gambar yang } \\
\text { belum pernah disisipi pesan } \\
\text { atav yang belum pernah di- } \\
\text { encode terlebih dahulv. Lalv } \\
\text { menekan tombol "DECODE" }\end{array}$ & 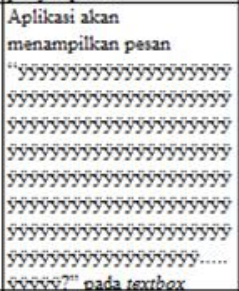 & Berhasil \\
\hline 3 & \begin{tabular}{|l|} 
Melakuk \\
an \\
proses \\
decode
\end{tabular} & $\begin{array}{l}\text { Memasulkkan gambar (bmp. } \\
\text { png) yang belum disisip pesan } \\
\text { dan mengisi key yang salah. } \\
\text { Lalu menekan tombol }\end{array}$ & $\begin{array}{l}\text { Aplikasi tidak akan } \\
\text { melakukan proses decode } \\
\text { dan akan menampilkan } \\
\text { message "Tidak ada }\end{array}$ & Berhasil \\
\hline 4 & \begin{tabular}{|l|} 
Melakuk \\
an \\
proses \\
decode.
\end{tabular} & $\begin{array}{l}\text { Memasukkan gambar(bmp. } \\
\text { png) yang sudah disisip pesan, } \\
\text { tanpa mengisi key. Lalv } \\
\text { menekan tombol "DECODE". }\end{array}$ & $\begin{array}{l}\text { Aplikasi akan melakukan } \\
\text { proses decode. Tapi, hasil } \\
\text { dari plaintext dan } \\
\text { plaintext (hex) tidak keluar, } \\
\text { hanya ciphertext saja yang } \\
\text { ditampilkan }\end{array}$ & Berhasil \\
\hline 5 & \begin{tabular}{|l|} 
Melakcuk \\
an \\
proses \\
decode.
\end{tabular} & $\begin{array}{l}\text { Memasukkan gambar(bmp, } \\
\text { png ) yang svdah disisipi } \\
\text { pesan, dan mengisi key yang } \\
\text { benar. Lalu menekan tombol } \\
\text { "DECODE". }\end{array}$ & $\begin{array}{l}\text { Aplikasi akan melakukan } \\
\text { proses decode dan akan } \\
\text { menampilkan hasil } \\
\text { ciphertext pesan yang } \\
\text { disisip dan menampilkan }\end{array}$ & Berhasil \\
\hline 6 & \begin{tabular}{|l|} 
Menyim \\
pan \\
Pesan.
\end{tabular} & $\begin{array}{l}\text { Melakukan proses menyimpan } \\
\text { pesan dengan menekan } \\
\text { tombol "SIMPAN" }\end{array}$ & $\begin{array}{l}\text { Aplikasi berhasil } \\
\text { menyimpan pesan. }\end{array}$ & Berhasil \\
\hline 7 & $\begin{array}{l}\text { Kembali } \\
\text { ke menv } \\
\text { utama }\end{array}$ & $\begin{array}{l}\text { Pengguna memilih tombol } \\
\text { "KEMBALI" }\end{array}$ & \begin{tabular}{|l|} 
Aplikasi melakukan proses \\
kembali ke menv utama
\end{tabular} & Berhasil \\
\hline
\end{tabular}

Dari hasil pengujian dengan menggunakan metode blackbox, kesimpulan yang didapat semua fungsi berjalan dengan baik tanpa adanya kesalahan pada kode program.

\section{Pengujian fidelity}

Tujuan dari pengujian ini adalah untuk mengetahui perubahan ukuran gambar dengan 2 (dua) jenis ekstensi berkas gambar yang digunakan sebagai wadah dari data atau informasi, yaitu .png dan .bmp.

Tabel 4. Pengujian fidelity

\begin{tabular}{|c|c|c|c|c|}
\hline Nama File & $\begin{array}{c}\text { Dimensi } \\
\text { (Ukuran) }\end{array}$ & $\begin{array}{c}\text { Panjang } \\
\text { pesan }\end{array}$ & $\begin{array}{c}\text { Ekstensi } \\
\text { gambar }\end{array}$ & $\begin{array}{c}\text { Ukuran } \\
\text { gambar }\end{array}$ \\
\hline \multirow{4}{*}{$\begin{array}{c}250 \\
\text { Kupukupu } \\
\text { png }\end{array}$} & $768 \times 512$ & \begin{tabular}{c} 
karakter \\
\cline { 2 - 5 }
\end{tabular} & .png & $843 \mathrm{~Kb}$ \\
\cline { 2 - 5 } & $(599 \mathrm{~kb})$ & $\begin{array}{c}1000 \\
\text { karakter }\end{array}$ & .png & $845 \mathrm{~Kb}$ \\
\cline { 2 - 5 } & $\begin{array}{c}2000 \\
\text { karakter }\end{array}$ & .png & $847 \mathrm{~Kb}$ \\
\cline { 2 - 5 } & $\begin{array}{c}250 \\
\text { karakter }\end{array}$ & .bmp & $1.12 \mathrm{Mb}$ \\
\cline { 2 - 5 } & $\begin{array}{c}1000 \\
\text { karakter }\end{array}$ & .bmp & $1.12 \mathrm{Mb}$ \\
\hline & $\begin{array}{c}2000 \\
\text { karakter }\end{array}$ &.$b m p$ & $1.12 \mathrm{Mb}$ \\
\hline
\end{tabular}

Kesimpulan dari tabel diatas, terlihat gambar berekstensi .png terjadi perbedaan ukuran saat terjadi penyisipan pesan dengan jumlah karakter yang berbeda. Sedangkan gambar yang berekstensi .bmp terlihat bahwa tidak ada perbedaan ukuran gambar meskipun disisipkan pesan dengan jumlah yang berbeda, hanya saja ukuran gambar dengan ekstensi .bmp lebih besar dari .png.

\section{Kesimpulan}

1. Penerapan steganografi dengan metode Least Significant Bit (LSB) dapat dikombinasikan bersama kriptografi AES. Hal ini dapat dibuktikan dengan data yang berhasil di enkripsi dan disisipkan kedalam gambar tanpa mengurangi kualitas gambar/citra asli secara signifikan, sehingga tidak dapat dibedakan dengan gambar/citra dari hasil penyisipan pesan.

2. Ukuran gambar dengan ekstensi .bmp lebih konsisten terhadap penyisipan informasi meskpun jumlah karakter atau huruf yang disisipkan berbeda jumlahnya.

3. Penerapan metode steganografi LSB dan algoritma kriptografi AES dapat diimplementasikan dalam sebuah aplikasi berbasis desktop. Sehingga pesan yang akan dikirimkan akan terlindungi dengan aman. Karena hanya orang yang berkepentingan yang dapat mengetahui pesan tersebut.

\section{Daftar Pustaka}

Ariyus, Dony. 2008. Pengantar Ilmu Kriptografi: Teori Analisis \& Implementasi. Penerbit Andi: Yogyakarta.

Syaiful Anwar, 2017, Implementasi Pengamanan Data Dan Informasi Dengan Metode Steganografi LSB Dan Algoritma Kriptografi AES, Universitas Budi Luhur, Jakarta Selatan.

Gede Wisnu Bhaudhayana dan I Made Widiartha, 2015, Implementasi Algoritma Kriptografi AES 256 Dan Metode Steganografi LSB Pada Gambar Bitmap, Universitas Udayana, Denpasar.

Ami Aisiah Ibrahim, 2017, Perancangan Pengamanan Data Menggunakan Algoritma AES (Advanced Encyption Standard), STMIK Antar Bangsa, Tanggerang.

Indra Suryanto, Drs. Cucu Suhery, M.A., dan Yulrio Brianorman, S.Si., M.T., 2017, Pengembangan Aplikasi Chat Messenger Dengan Metode Advanced Encryption Standard (AES) Pada Smartphone, Universitas Tanjungpura, Pontianak.

Chandra, A., Raharjo, W. S., dan Tampubolon, J. K., 2015, Implementasi steganografi dengan metode end of file pada teks yang terenkripsi menggunakan block cipher rivest code- 6 ke dalam citra, Jurnal Teknik Universitas Kristen Duta Wacana, No.1, Vol.11,:https://labti.ukdw.ac.id/ojs/index.php/infor matika/article/view/ 
Roger, S. Pressman, Ph.D., 2012, Rekayasa Perangkat Lunak (Pendekatan Praktisi), Ed.7, diterjemahkan oleh Andi, Yogyakarta.

Novianto, Dian. 2017. Optimasi Waktu Query Dan Filtering Nama Domain Pada Dns Server Lokal Menggunakan Bind 9. Jurnal Ilmiah Informatika $\begin{array}{lllll}\text { Global Vol. } & 8 & \text { No.1 }\end{array}$ http://ejournal.uigm.ac.id/index.php/IG/article/view 1320 